\title{
Secretion of hypothalamic and pituitary hormones by non-endocrine tumours
}

\author{
T. J. MARTIN \\ From the Department of Chemical Pathology, University of Sheffield Medical School, Beech Hill Road, \\ Sheffield S10 $2 R X$
}

That non-endocrine cancers can produce clinical syndromes of apparent hormone excess has been known for some time (Rees and Ratcliffe, 1974). Now there is ample clinical and biochemical evidence that many polypeptide hormones may be produced and released by human tumours which originate in tissues which are not normally regarded as sites for the physiological production of the hormones. In some instances-for example, inappropriate production by a cancer of adrenocorticotrophic hormone-that syndrome may be clinically obvious. Thus Cushing's syndrome in a patient with a relatively slowly growing lung cancer or carcinoid will be obvious. More commonly with ectopic ACTH production, however, the full clinical picture of Cushing's syndrome is not apparent-rather there is pronounced muscle weakness, hypokalaemic alkalosis, pigmentation, and very high levels of plasma cortisol and ACTH.

Most of the ectopic humoral syndromes are diagnosed on the clinical and biochemical improvement after tumour resection, on finding high plasma and tumour extract concentrations of hormones, in some patients on localisation of hormones in tumour cells by immunofluorescence, and on the presence of an arteriovenous gradient of hormone concentration across the tumour. There are now many instances of cultured cancer cells being shown to release hormone into the culture medium. In a few cases the biosynthesis of hormone has been demonstrated by the incorporation of radioactive amino-acids into the peptide.

Although most research in this area has been concentrated on the study of hormone production, presumably because hormones readily manifest their presence, other polypeptides also are produced and released by tumours in greater quantities than would be expected from the tissue of origin. These include enzymes such as alkaline phosphatase (Nathanson and Fishman, 1971), lysozyme (Kovanyi and Letnansky, 1971), amylase (Amman et al., 1972), and plasminogen activator (Davidson et al., 1969) as well as a variety of fetal proteins that are normally present in plasma only in small quantities during adult life (Alexander, 1972), such as carcinoembryonic antige (Gold, 1970) and alpha fetoprotein (Abelev, 1971)

\section{Cellular mechanisms}

The cellular mechanisms by which cancers produce ectopic hormone are not understood. There are various possibilities.

(1) Entrapment of circulating hormones by tumour capable of binding them has been discussee for some years. There is no evidence to support this and it seems unlikely.

(2) The neoplastic cells may have a disordeged mechanism for polypeptide synthesis so that randon production of polypeptide chains results. Some of thes polypeptides may have biological or immunologica properties that resemble known hormones. If thio theory were correct the production of a recognisable polypeptide would be unusual, which is not the case $\overrightarrow{0}$ and the particular polypeptide produced woul $\bar{\phi}$ account for only a small fraction of the cell outpue?

(3) Polypeptide production may originate fron material within a tumour-virus genome. There is evidence in vertebrates that somatic cells may con:tain the genetic information for producing tumouz viruses in an unexpressed form (Todaro and Huebner, 1972). Alternatively, if tumours are a resulक of new viral infections the new genetic material could be acquired during infection and tumour induction

(4) There is a general body of evidence that the hormonal peptides from cancers are very similar to or identical with known hormones or their precure sors, which suggests that part of the genetic code is being appropriately transcribed and translated. It this is indeed confirmed two general theories may account for ectopic hormone production.

(a) Pluripotentiality. If all adult cells contain a the genetic material that is needed to synthesise alo proteins which can be produced by the organism the production of an ectopic hormone may result fron genetic derepression taking place during cance development. 
(b) An alternative theory is that these particular tumours arise only from specialised cells within tissues (Cohnheim, 1889) and that the properties of these cells may include the capacity to produce polypeptides. The production of hormones becomes apparent when the mass of these cells increases. The modern development of Cohnheim's 'cell rest' hypothesis is that certain cells of the adult gastrointestinal tract, pancreas, thyroid, and pituitary share morphological and histochemical properties (Pearse, 1968) and have a common embryological origin from the neural crest (Pearse and Carvalheira, 1967; Pearse and Polak, 1971). When these cells become neoplastic or hyperplastic they retain the histochemical and ultrastructural characteristics of the group (Elias et al., 1972; Pearse and Polak, 1974). Multiple hormone production by such tumours (Law et al., 1965) or the production of another hormone which is usually produced by another cell of the series (Donahower et al., 1968) may be explained by this common origin.

Of all these theories $4(a)$ and $(b)$ are now the most popular, although either alone does not seem sufficient to explain the phenomenon. Any conclusions about the mechanisms of ectopic hormone production need to be based on careful clinical studies, since very little experimental evidence is available. Considerable information has been obtained from studies of patients with cancers producing 'pituitary' hormones.

\section{ACTH}

Although the syndrome occurs most commonly with oat cell carcinoma of the bronchus there have been a number of well documented cases associated with other cancers-particularly thymoma, bronchial carcinoid, medullary carcinoma of the thyroid, and islet cell carcinoma of the pancreas. This grouping of tumours favours the possibility that the tumour cells arise from a common embryological origin, or that the nature of the 'derepression' that takes place with these cancers may be such that the cellular genetic material coding for ACTH synthesis is reproducibly exposed. Thus theory $4(a)$ or $4(b)$ above might apply, or a combination of the two. This syndrome has been studied experimentally by Gewirtz and Yalow (1974), who obtained evidence of immunoreactive ACTH in extracts of lung tissue from smoking dogs.

The observation that immunoreactivity is often greater than bioactivity in tumour extracts (Rees and Ratcliffe, 1974) is important in deciding whether 'tumour' ACTH differs from 'pituitary' ACTH. Ratcliffe et al. (1972) and Orth et al. (1973) have evidence that tumours contain fragments of the ACTH molecule and, as expected, these are recog- nised to differing degrees by different antisera. It would also be expected that only some of the fragments would be biologically active. Gewirtz and Yalow (1974) have noted in plasma and in extracts of tumour from patients with the syndrome the presence of a high molecular weight form of ACTH ('big' ACTH) which can be converted to the same size as ACTH by mild trypsin treatment. Big ACTH was not found in plasma of patients with Addison's disease. Possibly this large molecule is a biosynthetic precursor of ACTH, but a precursor-product relationship has not been shown.

None of these observations excludes the possibility that the tumours are synthesising authentic ACTH, identical with the pituitary form. The persistence of a possible precursor and the generation of fragments could be explained by the absence from the tumour cells of the normal packaging and secretory mechanisms.

Clinically, the syndrome may be easy to recognise in those patients with relatively slowly growing tumours, and since the high steroid output contributes to the illness surgical removal of the tumour has been successful (Orth and Liddle, 1971). Treatment with metyrapone may be useful. A thymoma has been localised preoperatively by multiple venous sampling for ACTH assay and been successfully treated by surgery (Lowry et al., 1977). ACTH assay may be used in such patients to detect tumour recurrence.

\section{Growth hormone}

Fried (1943) noted the similarity between acromegaly and chronic hypertrophic pulmonary osteoarthropathy (HPOA). He thought that dyspituitarism was a possible cause of the latter syndrome. Steiner et al. (1968) and Dupont et al. (1970) reported that some patients with bronchogenic carcinoma and HPOA had raised growth hormone levels, but this metabolic abnormality is not invariably a feature of patients with HPOA (Cameron et al., 1969; Beck and Burger, 1972). Significant amounts of growth hormone have been found in bronchial carcinomas by several groups, and Beck and Burger (1972) have reported quite high levels in extracts of gastric carcinomas. Greenberg et al. (1972) have demonstrated synthesis of growth hormone by a lung tumour in cell culture.

The conclusion from these various studies is that tumour production of growth hormone can occur, that it is unlikely to be related to HPOA, and that no metabolic complication need be apparent. Clinically evident carbohydrate intolerance has not been reported, but failure of suppression of growth hormone during the glucose tolerance test has been described (Burger et al., 1970; Sparagana et al., 1971). 


\section{Antidiuretic hormone}

Inappropriate production of antidiuretic hormone $(\mathrm{ADH})$ with water retention and hyponatraemia has been recognised for some time in patients with oat cell carcinoma of the bronchus. Radioimmunoassay of $\mathrm{ADH}$ continues to present difficulties, but in studies carried out by a number of groups the tumour ADH closely resembles arginine vasopressin by chemical, immunological, and biological criteria (Barraclough et al., 1966). George et al. (1972) demonstrated the synthesis of vasopressin by a cancer in vitro by incubating tumour slices from a lung carcinoma, and Martin et al. (1972) found ADH activity released by cultured cells from a patient with inappropriate $\mathrm{ADH}$ production. In the latter experiments the ADH in serum, ascitic fluid, and culture medium was associated non-covalently with a larger protein. Hamilton et al. (1972) made a similar observation and, further, suggested that tumours might be producing neurophysin as well. If this is so it indicates that the tumour very closely reproduces the normal biosynthesis of $\mathrm{ADH}$. If neurophysin production does occur it provides an example of production of a 'hormone' which would not be evident clinically, since no biological effects of neurophysin are known.

\section{Other pituitary hormones}

Galactorrhoea as a result of ectopic prolactin production is recognised, and Turkington (1971) used cell culture to show release of biologically active prolactin into the medium by cells from a bronchogenic carcinoma and from a renal cell carcinoma associated with galactorrhoea. There are many reports of gonadotrophin production by cancers. If those tumours showing trophoblastic differentiation are excluded the condition has presented most commonly as gynaecomastia and galactorrhoea inpatients with carcinoma of the bronchus (Fusco and Rosen, 1966) or as precocious puberty in young males with liver tumours (McArthur et al., 1973). The problems of precisely identifying the hormone produced is compounded in the case of the gonadotrophic hormones by the cross-reactivity of antisera and by the possibility of separate release of $\alpha$ and $\beta$ subunits of the hormones. Tashjian et al. (1973) have shown dissociated release of the subunits of HCG in a cloned cell line from a bronchogenic carcinoma.

\section{Hypothalamic hormones}

If tumours are capable of producing hormones probably they might be shown to produce any of the range of 'releasing hormones', but very little information is available. Upton and Amatruda (1971) found evidence of corticotrophin-releasing activity in extracts from two primary cancers and from the metastases of one of them. Corticotrophin-releasing activity was evident in vivo and in vitro. This activity cannot be compared with the corresponding hypothalamic activity since neither agent has been isolated. The same can be said of the experiments of Beck et al. (1973), who found growth hormone-s releasing activity in extracts of human cancers $\overrightarrow{0}$ assayed by stimulating growth hormone releasefrom superfused rat pituitaries in vitro.

Since the discovery of the growth hormone release-inhibiting hormone (somatostatin) (Brazeau et al., 1973) there has been some uncertainty whether. a specific hypothalamic hormone stimulating growth:hormone release exists, although there have beenis many experiments showing this property in hypo-o thalamic extracts (Krulich et al., 1968; Schally et al., $?$ 1969; Beck et al., 1973). Even if no specific hypo- $-\vec{c}$ thalamic factor exists, however, there may be other substances capable of stimulating pituitary growth hormone release and thereby cause the abnormalities known to occur in some patients with cancer $\overrightarrow{0}$ (Sparagana et al., 1971). High plasma growth h8ु-के mone levels and failure of suppression after glucose have been found in eight out of 18 patients wetho bronchial carcinoid tumours (Feldman et al., 197해. The fact that in this series the abnormality of growtho hormone seemed unrelated to excess serotonin pro-这 duction raised the possibility that carcinoid tumours produce some other factor promoting growth hor-윽 mone release.

The best evidence that tumours can produce hypothalamic hormones has been obtained recently by Jeffcoate et al. (1977) in a patient with a thymomao producing not only ACTH with Cushing's syndromeo but also somatostatin and 'LH-RH, both readily? measured by radioimmunoassay and showing, wheno diluted, a curve parallel to that of standards.

\section{Conclusion}

The difficulties in diagnosing and recognising the syndromes due to ectopic pituitary hormones ares considerable, and a new dimension has been added with the discovery of the hypothalamic hormones. If 0 as seems likely, cancers can also produce these, ando perhaps also other brain peptides, research in this area will certainly be difficult. But there are most remarkable possibilities for determining the clinicalo metabolic effects of cancers and discovering causes? for the many humoral manifestations of malignanto disease. 


\section{References}

Abelev, G. I. (1971). Alpha-fetoprotein in oncogenesis and its association with malignant tumours. Advances in Cancer Research, 14, 295.

Alexander, P. (1972). Foetal 'antigens' in cancer. Nature (London), 235, 137.

Amman, R., Berk, J. E., Fridhandler, L., Ueda, M., and Wegman, W. (1972). Hyperamylasemia in cancer of the lung. (Abstract.) Clinical Research, 20, 562.

Barraclough, M. A., Jones, J. J., and Lee, J. (1966). Production of vasopressin by anaplastic oat cell carcinoma of the bronchus. Clinical Science, 31, 135.

Beck, C., and Burger, H. G. (1972). Evidence for the presence of immunoreactive growth hormone in cancers of the lung and stomach. Cancer (Philadelphia), 30, 75.

Beck, C., Larkins, R. G., Martin, T. J., and Burger, H. G. (1973). Stimulation of growth hormone release from superfused rat pituitary by extracts of hypothalamus and of human lung tumours. Journal of Endocrinology, 59, 325.

Brazeau, P., Vale, W., Burgus, R., Ling, N., Butcher, M., Rivier, J., and Guillemin, R. (1973). Hypothalamic polypeptide that inhibits the secretion of immunoreactive pituitary growth hormone. Science, 179, 77.

Burger, H. G., Cameron, D. P., Catt, K. J., and Atkins, A. (1970). Growth hormone secretion and osteoarthropathy in brochogenic carcinoma (Abstract). Australasian Annals of Medicine, 19, 73.

Cameron, D. P., Burger, H. G., DeKretzer, D. M., Catt, K. J., and Best, J. B. (1969). On the presence of immunoreactive growth hormone in a bronchogenic carcinoma. Australasian Annals of Medicine, 18, 143.

Cohnheim, J. (1889). Lectures on General Pathology, translated by A. B. McKee, Sect. II, p. 789. New Sydenham Society, London.

Davidson, J. F., McNichol, G. P., Frank, G. L., and Anderson, T. J. (1969). Plasminogen activator-producing tumour. British Medical Journal, 1, 88.

Donahower, G. F., Schumacher, O. P., and Hazard, J. B. (1968). Medullary carcinoma of the thyroid gland, a cause of Cushing's syndrome: report of two cases. Journal of Clinical Endocrinology, 28, 1199.

Dupont, B., Høyer, I., Borgeskov, S., and Nerup, J. (1970). Plasma growth hormone and hypertrophic osteoarthropathy in carcinoma of the bronchus. Acta Medica Scandinavica, 188, 25.

Elias, E., Polak, J. M., Bloom, S. R., Pearse, A. G. E., Welbourn, R. B., Booth, C. C., Kuzio, M., and Brown, J. C. (1972). Pancreatic cholera due to production of gastric inhibitory polypeptide. Lancet, 2, 791.

Feldman, J. M., Plonk, J. W., Bivens, C. H., Lebovitz, H. E., and Handwerger, S. (1975). Growth hormone and prolactin secretion in the carcinoid syndrome. American Journal of Medical Sciences, 269, 333.

Fried, B. M. (1943). Chronic pulmonary osteoarthropathy: dyspituitarism as a probable cause. Archives of Internal Medicine, 72, 565.

Fusco, F. D., and Rosen, S. W. (1966). Gonadotrophinproducing anaplastic large-cell carcinomas of the lung. New England Journal of Medicine, 275, 507.

George, J. M., Capen, C. C., and Phillips, A. S. (1972). Biosynthesis of vasopressin in vitro and ultrastructure of a bronchogenic carcinoma. Journal of Clinical Investigation, $51,141$.

Gewirtz, G., and Yalow, R. S. (1974). Ectopic ACTH production in carcinoma of the lung. Journal of Clinical Investigation, 53, 1022.

Gold, P. (1970). The role of immunology in human cancer research. Canadian Medical Association Journal, 103, 1043.

Greenberg, P. B., Beck, C., Martin, T. J., and Burger, H. G.
(1972). Synthesis and release of human growth hormone from lung carcinoma in cell culture. Lancet, $1,350$.

Hamilton, B. P. M., Upton, G. V., and Amatruda, T. T., Jr. (1972). Evidence for the presence of neurophysin in tumors producing the syndrome of inappropriate ant diuresis. Journal of Clinical Endocrinology, 35, 764.

Jeffcoate, W. J., Mortimer, C. H., Rees, L. H., Tomlin, S., Rees, G. M., Nicol, W. D., Stansfield, A. G., and Besser, G. M. (1977). Cushing's syndrome: the localisation of an ectopic hormone secreting tumour. In preparation.

Kovanyi, G., and Letnansky, K. (1971). Urine and blood serum muramidase (lysozyme) in patients with urogenital tumours. European Journal of Cancer, 7, 25.

Krulich, L., Dhariwal, A. P. S., and McCann, S. M. (1968). Stimulatory and inhibitory effects of purified hypothalamic extracts on growth hormone release from rat pituitary in vitro. Endocrinology, 83, 783.

Law, D. H., Liddle, G. W., Scott, H. W., Jr., and Tauber, S. D. (1965). Ectopic production of multiple hormones (ACTH, MSH and gastrin) by a single malignant tumor. New England Journal of Medicine, 273, 292.

Lowry, P. J., Rees, L. H., and Tomlin, S. (1977). In preparation.

McArthur, J. W., Toll, G. D., Russfield, A. B., Reiss, A. M., Quinby, W. C., and Baker, W. H. (1973). Sexual precocity attributable to ectopic gonadotrophin secretion by hepatoblastoma. American Journal of Medicine, 54, 390.

Martin, T. J., Greenberg, P. B., Beck, C, and Johnston, C. I. (1972). Synthesis of peptide hormones by human tumours in cell culture, Excerpta Medica International Congress Series, 273, p. 1198-1204.

Nathanson, J., and Fishman, W. H. (1971). New observations on the Regan isoenzyme of alkaline phosphatase in cancer patients. Cancer (Philadelphia), 27, 1388.

Orth, D. N., and Liddle, G. W. (1971). Results of treatment in 108 patients with Cushing's syndrome. New England Journal of Medicine, 285, 243.

Orth, D. N., Nicholson, W. E., Mitchell, W. M., Island, D. P., and Liddle, G. W. (1973). Biologic and immunologic characterization and physical separation of ACTH and ACTH fragments in the ectopic ACTH syndrome. Journal of Clinical Investigation, 52, 1756.

Pearse, A. G. E. (1968). Common cytochemical and ultrastructural characteristics of cells producing polypeptide hormones (the APUD series) and their relation to thyroid and ultimobranchial $\mathrm{C}$ cells and calcitonin. Proceedings of the Royal Society (Biology), 170, 71.

Pearse, A. G. E., and Carvalheira, A. F. (1967). Cytochemical evidence for an ultimobranchial origin of rodent thyroid C cells. Nature (London), 214, 929.

Pearse, A. G. E., and Polak, J. M. (1971). Neural crest origin of the endocrine polypeptide (APUD) cells of the gastrointestinal tract and pancreas. Gut, 12, 783.

Pearse, A. G. E., and Polak, J. M. (1974). Endocrine tumours of neural crest origin. Neurolophomas, apudomas and the APUD concept. Medical Biology, 52, 3.

Ratcliffe, J. G., Knight, R. A., Besser, G. M., Landon, J., and Stansfield, A. G. (1972). Tumour and plasma ACTH concentrations in patients with and without the ectopic ACTH syndrome. Clinical Endocrinology, 1, 27.

Rees, L. H., and Ratcliffe, J. G. (1974). Ectopic hormone production by non-endocrine tumours. Clinical Endocrinology, 3, 263.

Schally, A. V., Sawano, S., Arimura, A., Barrett, J. F., Wakabayashi, I., and Bowers, C. Y. (1969). Isolation of growth hormone-releasing hormone (GRH) from porcine hypothalmi. Endocrinology, 84, 1493.

Sparagana, M., Phillips, C., Hoffman, C., and Kucera, L. (1971). Ectopic growth hormone syndrome associated with 
lung cancer. Metabolism: Clinical and Experimental, 20, 730 .

Steiner, H., Dahlbäck, O., and Waldenström, J. (1968) Ectopic growth-hormone production and osteoarthropathy in carcinoma of the bronchus. Lancet, 1, 783.

Tashjian, A. H., Jr, Weintraub, B. D., Barowsky, N. J., Rabson, A. S., and Rosen, S. W. (1973). Subunits of human chorionic gonadotrophin: unbalanced synthesis and secretion by clonal cell strains derived from a bronchogenic carcinoma. Proceedings of the National Academy of Sciences of the United States of America, 71, 1419.
Todaro, G. J., and Huebner, R. J. (1972). The viral oncogenea hypothesis: new evidence. Proceedings of the Nationa $\vec{B}$ Academy of Sciences of the United States of America, 69음 1009.

Turkington, R. W. (1971). Ectopic production of prolactin...厂5 New England Journal of Medicine, 285, 1455.

Upton, G. V., and Amatruda, T. T., Jr. (1971). Evidence fo the presence of tumor peptides with corticotrophin releasing-factor-like activity in the ectopic ACTH syn-? drome. New England Journal of Medicine, 285, 419. 